УДК 615.322: 339.13.017

DOI https://doi.org/10.11603/2312-0967.2021.4.12512

\title{
АНТИМІКРОБНА АКТИВНІСТЬ НАСТОЙОК ТА РІДКИХ ЕКСТРАКТІВ ІЗ КОРЕНІВ ЛОПУХА ВЕЛИКОГО, ЛОПУХА МАЛОГО ТА ЛОПУХА ПАВУТИНИСТОГО
}

\author{
Т. В. Опрошанська ${ }^{1}$, Т. П. Осолодченко ${ }^{2}$, О. П. Хворост ${ }^{1}$ \\ Національний фрармацевтичний університет ${ }^{1}$ \\ Державна Установа «Інститут мікробіології та імунології імені І. І. Мечникова \\ Національної академії медичних наук України»² \\ arctium@ukr.net
}

\section{ІНФОРМАЦІЯ}

Надійшла до редакції / Received: 30.11.2021

Після доопрацювання / Revised: 02.12 .2021

Прийнято до друку / Accepted: 06.12 .2021

\section{Ключові слова:}

лопух;

корінь;

настойка;

рідкий екстракт;

антимікробна активність.

\section{АНОТАЦІЯ}

Мета роботи. Дослідити антимікробну активність настойок і рідких екстрактів із коренів лопуха великого, лопуха малого та лопуха павутинистого.

Матеріали і методи. Настойки та рідкі екстракти з сировини готували класичним методом мацерації при кімнатній температурі, екстрагент $50 \%$ спирт етиловий. Вивчення антимікробної активності настойок і рідких екстрактів проводили методом дисузії в агар та методом серійних розведень. Для оцінки активності препаратів використовували референсштами Staphylococcus aureus ATCC 25923, Escherichia coli ATCC 25922, Pseudomonas aeruginosa ATCC 27853, Bacillus subtilis ATCC 6633, Proteus vulgaris ATCC 4636 та Candida albicans ATCC 885-653. Визначали мінімальну інгібуючу (МІК) та мінімальну бактерицидну концентрацію (МБцК) рідких екстрактів.

Результати й обговорення. Рідкі екстракти з коренів лопуха великого, лопуха малого, лопуха павутинистого проявили значнішу антимікробну активність, ніж настойки, відносно усіх штамів, що застосували у дослідженнях. Всі штами мікроорганізмів найчутливішими були до рідкого екстракту з кореня лопуха малого. Настойки та рідкі екстракти проявили досить високу активність відносно мікроорганізмів Basillus subtilis ATCC 6633 і Staphylococcus aureus ATCC 25923. Вивчено МІК та МБцК рідких екстрактів із коренів лопуха великого, лопуха малого, лопуха павутинистого, значення яких у рідких екстрактів із коренів лопуха великого та лопуха малого відносно Escherichia

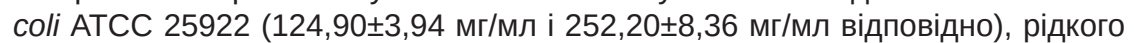
екстракту 3 кореня лопуха малого відносно Proteus vulgaris ATCC 4636 $(249,80 \pm 10,04$ мг/мл і 505,20 19,88 мг/мл) і рідкого екстракту 3 коренів

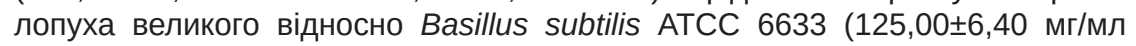

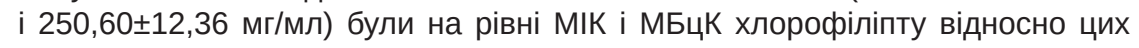
штамів мікроорганізмів.

Висновки. Вивчено спектр антимікробної активності настойок та рідких екстрактів із коренів лопуха великого, лопуха малого, лопуха павутинистого відносно 6 музейних штамів мікроорганізмів та визначено МІК і МБцК рідких екстрактів. Рідкі екстракти мали вищу антимікробну активність, ніж настойки. Отримані дані будуть використані в подальших дослідження настойок та рідких екстрактів.

ISSN 2312-0967. Фармацевтичний часопис. 2021. № 4 
Фармакологічні дослідження біологічно активних речовин Pharmacological researches of biologically active substances

Вступ. Рослинні препарати є невід'ємною частиною традиційної медицини. Зважаючи на значну комплаєнтність, мультивекторну дію та доступну вартість такі лікарські фрітопрепарати, як настойки не втрачають своєї популярності в практичній фармації [1]. Широко досліджують антимікробні властивості настойок, які випускає вітчизняна фрармацевтична промисловість відносно музейних та клінічних штамів мікроорганізмів [2, 3]. Якщо антимікробна активність відносно музейних штамів мікроорганізмів може бути передбачуваною, то у випадках із клінічними штамами мікроорганізмів виявлено антимікробну дію настойок може свідчити про перспективність цієї групи лікарських препаратів як нових джерел ефективних засобів лікування інфекцій, що викликані антибіотикорезистентними клінічними штамами мікроорганізмів [3]. Ряд видів лікарської рослинної сировини містить поліфреноли, зокрема фрлавоноїди, що здатні проявляти потужну антибактеріальну дію, в тому числі і проти грамнегативних мікроорганізмів, яка, ймовірно, зумовлена їхньою здатністю інгібувати ДНК-гіразу, порушувати цілісність клітинної мембрани та впливати на енергетичні метаболічні процеси бактерій [4].

Аналіз асортименту фрітопрепаратів на фрармацевтичному ринку показав відсутність лікарських монозасобів на основі сировини рослин роду лопух, водночас корені лопуха входять до складу складних зборів «Детоксифіт» та «Нефрофріт», лікарського засобу «Аллотон» (розчин для зовнішнього застосування), а також дієтичних добавок та косметичних засобів [5]. Хімічний склад сировини та аспекти її застосування у науковій та народній медицині яскраво демонструють можливості створення низки лікарських засобів із сировини рослин роду лопух різної спрямованості дії $[6,7]$.

Науковці широко досліджують біологічну дію витяжок із насіння, листя та коренів лопуха великого. Так, за результатами досліджень виявлено, що корені лопуха проявляють гепатопротекторну, протизапальну та антирадикальну активність, яка зумовлена наявністю похідних кофеоїлхінної кислоти. Насіння, що містить лігнани арктиїн та арктигенін, має протипухлинну активність [8].

У листі лопуха великого за допомогою ультраефективної рідинної хроматографрії-мас-спектрометрії (UPLC-MS) (UPLC-MS аналіз використовували для отримання метаболічних «відбитків пальців» фрракцій листя лопуха) ідентифріковано 11 активних сполук (хлорогенова кислота, кавова кислота, п-кумарова кислота, кверцетин, урсолова кислота, рутин, цинарин, лютеолін, кроцин, бензойна кислота та тенацисозид I), що запобігають утворенню біоплівок Escherichia coli i Salmonella Typhimurium. Це може бути використано при зберіганні харчових продуктів, зокрема, свинини [9-11].

Сировина лопуха великого містить сполуки, які зменшують розмір передпухлинних уражень та демонструють тенденції зниження проліферації гепатоцитів всередині них, що приводить до зниження фрактору ризику виникнення гепатоцелюлярної карцино- ми [12]. Протиракові властивості сполук сировини лопуха великого включають інгібування проліферації клітин ангіогенезу та апоптозу, що зумовлює протиракові властивості [13].

Водний екстракт кореня лопуха великого можна використовувати як альтернативний засіб лікування за рахунок регулювання проліфрерації та дифреренціювання мезенхімальних стовбурових клітин [14]. Водна витяжка кореня лопуха великого покращує запальний статус та окиснювальний стрес при остеоартритах колінних суглобів [15]. Його антиоксидантна, протизапальна і гіполіпідемічна активність та захисна дія на слизову оболонку сприяє застосуванню цієї сировини як фрункціональної їжі [16].

На сьогодні популярні дослідження антимікробних та антиоксидантних властивостей сировини лопуха великого [17, 18].

У межах вивчення антибактеріального, антибіотико-плівчастого та антиоксидантного впливу низькомолекулярних пептидів коренів лопуха великого доведено їх противугровий ефект та можливість розробки на їх основі активних лікарських засобів [19].

Зважаючи на вищенаведену інформацію, створення галенових засобів із коренів поширених у країні рослин роду лопух та встановлення їхньої антимікробної активності є актуальним.

Мета роботи - дослідити антимікробну активність настойок та рідких екстрактів із коренів лопуха великого, лопуха малого та лопуха павутинистого.

Матеріали і методи. Настойки з сировини готували класичним методом мацерації при кімнатній температурі, співвідношення сировина-готовий продукт 1:5, екстрагент - 50 \% спирт етиловий. Рідкі екстракти готували при співвідношенні сировина-готовий продукт 1:1, час настоювання та екстрагент аналогічні використаним у технології виготовлення настойок.

Для дослідження були використані еталонні тесткультури грампозитивних і грамнегативних бактерій, які належать до різних таксономічних груп: Staphylococcus aureus ATCC 25923, Escherichia coli ATCC 25922, Pseudomonas aeruginosa ATCC 27853, Bacillus subtilis ATCC 6633, Proteus vulgaris ATCC 4636. Протигрибкову дію зразків досліджено на рефрерентному штамі Candida albicans ATCC 885-653. Зазначений набір тест-штамів є загальноприйнятим при первинному визначенні протимікробної дії. Усі тест-культури було одержано з лабораторії медичної мікробіології музею мікроорганізмів ДУ «IMI HAMH». Середовища для культивування застосовували відповідно до виду мікроорганізмів згідно з існуючими методичними розробками і рекомендаціями.

Визначення чутливості штамів мікроорганізмів до антибактеріальних лікарських засобів проводили відповідно до методичних вказівок «Визначення чутливості мікроорганізмів до антибактеріальних препаратів» (наказ Міністерства охорони здоров'я України від 05.04.2007 р. № 167) методом колодязів на середо-

ISSN 2312-0967. Pharmaceutical review. 2021. № 4 
Фармакологічні дослідження біологічно активних речовин Pharmacological researches of biologically active substances

вищі Мюллера - Хінтона (HIMediaLaboratorlesPvt. Ltd India). Середовище готували відповідно до інструкції виробника. Чутливість грибів визначали на Сабуродекстрозному агарі. Визначення чутливості дослідних речовин проводили на двох шарах поживного середовища, які розливали у чашки Петрі. Нижній шар складався 3 агар-агару (10 мл). На нього встановлювали 3-6 металевих стерильних циліндрів діаметром 8 мм та заввишки 10 мм. Навколо циліндрів заливали верхній шар (14 мл поживного середовища +1 мл мікробного розчину 0,5 од. за шкалою McFarland), який складався 3 поживного агаризованого середовища з відповідним стандартом добової культури мікроорганізму. Після застигання стерильним пінцетом виймають колодязі і в лунки вносять дослідну речовину (0,3 мл).

Оцінку антибактеріальної активності дослідних речовин проводили вимірюванням діаметра зон затримки росту:

10 мм - мікроорганізм не чутливий до дослідної речовини;

10-15 мм - мікроорганізм слабочутливий до дослідної речовини;

15-25 мм - мікроорганізм чутливий до дослідної речовини;

25 мм та вище - мікроорганізм високочутливий до даної речовини

Визначення протимікробної та антикандидозної дії проводили стандартним методом двократних серійних розведень у поживному бульйоні (макрометод). Тестування проводили в об'ємі 1 мл кожного розведення речовин із кінцевою концентрацією досліджуваного мікроорганізму приблизно $5 \times 10^{5}$ КУО/мл. Після інкубації впродовж доби або 48-72 годин для культур
Candida spp., пробірки з посівами переглядали у промінному світлі для визначення наявності росту мікроорганізму. Мінімальна інгібуюча концентрація (МІК) встановлювалась за найменшою концентрацією дослідної речовини, яка пригнічувала видимий ріст культури. Для визначення мінімальної бактерицидної концентрації (МБцК) виконували дозовані висіви на тверде поживне середовище (агар Мюллер - Хінтона) культуральної рідини з усіх пробірок, у яких не спостерігали росту мікроорганізму. За МБцК вважали найнижчу концентрацію, яка викликала загибель не менше 99,9 \% бактерій. При проведенні дослідів додатково проводили контроль росту культури в середовищі без дослідних речовин, у розчиннику; контроль чистоти суспензії мікроорганізму (шляхом висіву на неселективні середовища) та стерильності середовища.

Приготування суспензій мікроорганізмів із визначеною концентрацією мікробних клітин (оптична щільність) проводили за допомогою стандарту каламутності (0,5 од. за шкалою McFarland). Використовували прилад Densi-La-Meter (виробництва PLIVALachema, Чехія; довжина хвилі 540 нм). Суспензію готували згідно з інструкцією до приладу та інформаційного листа про нововведення в системі охорони здоров'я № 163-2006 «Стандартизація приготування мікробних суспензій», м. Київ. Синхронізацію культур проводили за допомогою низької температури $\left(4^{\circ} \mathrm{C}\right)$.

Як рефреренс-препарат використовували Хлорофіліпт (розчин спиртовий 10 мг/мл, серія 020121, ТОВ «Фармацевтична компанія «Здоров'я»).

Результати й обговорення. Результати дослідження антимікробної активності настойок та рідких екстрактів із коренів лопуха великого, лопуха малого, лопуха павутинистого узагальнено в таблицях 1 і 2.

\section{Таблиця 1}

Спектр антимікробної активності настойок та рідких екстрактів із коренів лопуха великого, лопуха малого, лопуха павутинистого

\begin{tabular}{|l|c|c|c|c|c|c|}
\hline \multirow{2}{*}{ Об'єкт } & \multicolumn{5}{|c|}{ Діаметр затримки росту мікроорганізму, мм } \\
\cline { 2 - 7 } & $\begin{array}{c}\text { Staphylococcus } \\
\text { aureus ATCC } \\
25923\end{array}$ & $\begin{array}{c}\text { Escherichia } \\
\text { coli ATCC } \\
25922\end{array}$ & $\begin{array}{c}\text { Proteus } \\
\text { vulgaris } \\
\text { ATCC 4636 }\end{array}$ & $\begin{array}{c}\text { Pseudomonas } \\
\text { aeruginosa } \\
\text { ATCC 27853 }\end{array}$ & $\begin{array}{c}\text { Basillus } \\
\text { subtilis } \\
\text { ATCC 6633 }\end{array}$ & $\begin{array}{c}\text { Candida } \\
\text { albicans ATCC } \\
653 / 885\end{array}$ \\
\hline $\begin{array}{l}\text { Настойка 3 коренів л. } \\
\text { великого }\end{array}$ & $23,20 \pm 1,04$ & $18,80 \pm 1,04$ & $17,00 \pm 0,88$ & $22,00 \pm 0,88$ & $24,20 \pm 1,04$ & $19,40 \pm 0,68$ \\
\hline $\begin{array}{l}\text { Настойка з коренів л. } \\
\text { малого }\end{array}$ & $23,80 \pm 1,04$ & $19,20 \pm 1,04$ & $18,20 \pm 1,04$ & $22,40 \pm 0,68$ & $24,00 \pm 0,88$ & $18,60 \pm 0,68$ \\
\hline $\begin{array}{l}\text { Настойка з коренів л. } \\
\text { павутинистого }\end{array}$ & $22,00 \pm 0,88$ & $19,80 \pm 1,04$ & $17,80 \pm 1,04$ & $23,60 \pm 1,11$ & $23,80 \pm 1,04$ & $18,20 \pm 1,04$ \\
\hline $\begin{array}{l}\text { Рідкий екстракт 3 } \\
\text { коренів л. великого }\end{array}$ & $24,80 \pm 1,04$ & $23,80 \pm 1,04$ & $21,00 \pm 0,88$ & $25,20 \pm 1,28$ & $24,80 \pm 1,04$ & $21,80 \pm 1,04$ \\
\hline $\begin{array}{l}\text { Рідкий екстракт 3 } \\
\text { коренів л. малого }\end{array}$ & $26,80 \pm 1,04$ & $23,80 \pm 1,04$ & $22,80 \pm 1,04$ & $26,80 \pm 1,28$ & $28,20 \pm 1,04$ & $22,20 \pm 1,04$ \\
\hline $\begin{array}{l}\text { Рідкий екстракт } \\
\text { з коренів л. } \\
\text { павутинистого }\end{array}$ & $25,20 \pm 1,04$ & $21,60 \pm 1,11$ & $19,80 \pm 1,04$ & $24,60 \pm 1,21$ & $25,40 \pm 1,11$ & $20,60 \pm 1,11$ \\
\hline «Хлорофіліпт» & $29,40 \pm 0,68$ & $25,60 \pm 0,68$ & $23,40 \pm 0,68$ & $24,60 \pm 0,68$ & $33,20 \pm 1,04$ & $24,60 \pm 0,68$ \\
\hline
\end{tabular}

ISSN 2312-0967. Фармацевтичний часопис. 2021. № 4 
Фармакологічні дослідження біологічно активних речовин Pharmacological researches of biologically active substances

\section{Таблиця 2}

Мінімальна інгібуюча та мінімальна бактерицидна концентрація рідких екстрактів із коренів лопуха великого, лопуха малого, лопуха павутинистого

\begin{tabular}{|c|c|c|c|c|c|c|}
\hline \multirow{2}{*}{ Об'єкт } & \multicolumn{2}{|c|}{$\begin{array}{c}\text { Staphylococcus aureus } \\
\text { ATCC } 25923\end{array}$} & \multicolumn{2}{|c|}{$\begin{array}{l}\text { Escherichia coli ATCC } \\
25922\end{array}$} & \multicolumn{2}{|c|}{$\begin{array}{l}\text { Proteus vulgaris ATCC } \\
4636\end{array}$} \\
\hline & $\begin{array}{l}\text { MIK } \\
\text { Мг/Мл }\end{array}$ & МБцК мг/мл & $\begin{array}{l}\text { MIK } \\
\text { Мг/Мл }\end{array}$ & $\begin{array}{l}\text { МБцК } \\
\text { Мг/Мл }\end{array}$ & $\begin{array}{l}\text { MIK } \\
\text { Мг/Мл }\end{array}$ & МБцК мг/мл \\
\hline $\begin{array}{l}\text { Рідкий екстракт з коренів } \\
\text { л. великого }\end{array}$ & $62,52 \pm 2,18$ & $125,40 \pm 6,00$ & $124,90 \pm 3,94$ & $252,20 \pm 8,36$ & $249,80 \pm 9,28$ & $498,40 \pm 17,02$ \\
\hline $\begin{array}{l}\text { Рідкий екстракт з коренів } \\
\text { л. малого }\end{array}$ & $62,50 \pm 1,97$ & $125,40 \pm 5,32$ & $125,00 \pm 3,93$ & $251,40 \pm 8,68$ & $249,80 \pm 10,04$ & $505,20 \pm 19,88$ \\
\hline $\begin{array}{l}\text { Рідкий екстракт з коренів } \\
\text { л. павутинистого }\end{array}$ & $62,40 \pm 1,99$ & $125,40 \pm 5,31$ & $62,60 \pm 1,88$ & $124,80 \pm 6,05$ & $124,00 \pm 5,20$ & $250,60 \pm 9,20$ \\
\hline «Хлорофріліпт-Здравофрарм» & $125,40 \pm 5,32$ & $249,80 \pm 7,73$ & $125,40 \pm 6,00$ & $252,20 \pm 8,36$ & $500,20 \pm 17,27$ & $500,40 \pm 17,32$ \\
\hline
\end{tabular}

Продовження табл. 2

\begin{tabular}{|c|c|c|c|c|c|c|}
\hline \multirow{2}{*}{ Об'єкт } & \multicolumn{2}{|c|}{$\begin{array}{c}\text { Pseudomonas aeruginosa } \\
\text { ATCC } 27853\end{array}$} & \multicolumn{2}{|c|}{$\begin{array}{c}\text { Basillus subtilis ATCC } \\
6633\end{array}$} & \multicolumn{2}{|c|}{$\begin{array}{c}\text { Candida albicans ATCC } \\
653 / 885 \\
\end{array}$} \\
\hline & $\begin{array}{l}\text { МIK } \\
\text { Мг/Мл }\end{array}$ & $\begin{array}{l}\text { МБцК } \\
\text { Мг/Мл }\end{array}$ & $\begin{array}{l}\text { МIK } \\
\text { Мг/Мл }\end{array}$ & МБцК мг/мл & $\begin{array}{l}\text { МIK } \\
\text { Мг/Мл }\end{array}$ & МБцК мг/мл \\
\hline $\begin{array}{l}\text { Рідкий екстракт з коренів } \\
\text { л. великого }\end{array}$ & $124,60 \pm 3,78$ & $249,80 \pm 7,73$ & $125,00 \pm 6,40$ & $250,60 \pm 12,36$ & $124,80 \pm 6,18$ & $250,20 \pm 11,81$ \\
\hline $\begin{array}{l}\text { Рідкий екстракт з коренів } \\
\text { л. малого }\end{array}$ & $252,20 \pm 8,35$ & $500,20 \pm 17,27$ & $62,10 \pm 2,99$ & $124,80 \pm 4,77$ & $125,40 \pm 5,17$ & $251,00 \pm 8,88$ \\
\hline $\begin{array}{l}\text { Рідкий екстракт з коренів } \\
\text { л. павутинистого }\end{array}$ & $125,40 \pm 4,85$ & $250,60 \pm 9,20$ & $62,20 \pm 2,84$ & $124,80 \pm 6,05$ & $125,20 \pm 4,34$ & $250,40 \pm 9,57$ \\
\hline «Хлорофріліпт-Здравофрарм» & $249,80 \pm 10,04$ & $502,50 \pm 19,23$ & $125,00 \pm 3,90$ & $249,80 \pm 7,73$ & $250,60 \pm 7,80$ & $500,20 \pm 17,21$ \\
\hline
\end{tabular}

Рідкі екстракти з коренів лопуха великого, лопуха малого, лопуха павутинистого проявили значнішу антимікробну активність, ніж настойки відносно усіх штамів, що застосували у дослідженнях. Найчутливішими всі штами мікроорганізмів були до рідкого екстракту з кореня лопуха малого. Найбільший діаметр затримки росту мікроорганізмів під дією настойки 3 кореня лопуха великого та лопуха малого був у Basillus subtilis ATCC $6633 \quad(24,20 \pm 1,04$ мм та

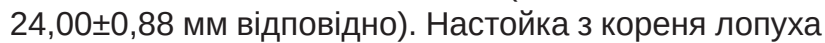
павутинистого затримувала ріст даного мікроорганіз-

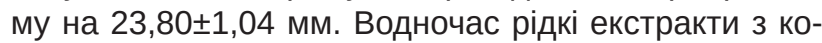
реня лопуха великого, лопуха малого і лопуха павутинистого затримували ріст вищевказаного мікроор-

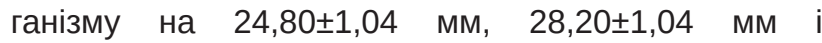

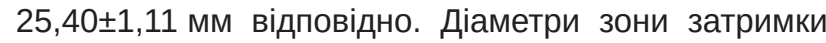
росту Pseudomonas aeruginosa АТСС 27853 під впливом досліджуваних настойок та рідких екстрактів із кореня лопуха великого, лопуха павутинистого були на рівні діаметрів зон затримки росту під впливом хлорофріліпту. Рідкий екстракт з кореня лопуха малого проявив вищу активність до мікроорганізму Pseudomonas aeruginosa ATCC 27853 (діаметр за-

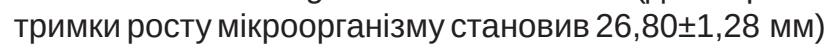
порівняно 3 хлорофріліптом (діаметр зони затримки

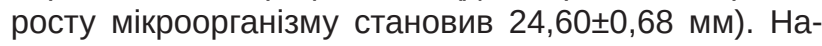

стойки та рідкі екстракти проявили досить високу активність відносно Staphylococcus aureus ATCC 25923 (див. табл. 1).

Оскільки рідкі екстракти з кореня лопуха великого, лопуха малого і лопуха павутинистого проявили вищу антимікробну активність, ніж настойки, тому було вивчено їхні МІК та МБцК.

МІК та МБцК рідких екстрактів з коренів лопуха великого та лопуха малого відносно Escherichia coli

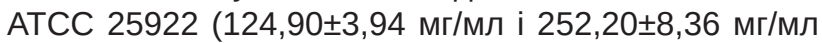
відповідно), рідкого екстракту з кореня лопуха малого відносно Proteus vulgaris АТСС 4636

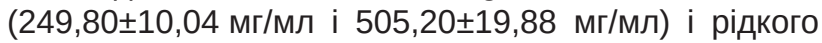
екстракту з коренів лопуха великого відносно Basillus subtilis ATCC $6633 \quad(125,00 \pm 6,40 \quad$ мг/мл і

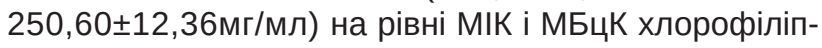
ту відносно цих штамів мікроорганізмів.

Висновки. Настойки та рідкі екстракти з коренів лопуха великого, лопуха малого та лопуха павутинистого були найефективнішими проти Basillus subtilis ATCC 6633, Pseudomonas aeruginosa ATCC 27853 та Staphylococcus aureus ATCC 25923. Рідкі екстракти проявили вищу антимікробну активність, ніж настойки, тому було визначено їхній МІК і МБцК. Найвищу активність до всіх штамів мікроорганізмів проявив рідкий екстракт із кореня лопу-

ISSN 2312-0967. Pharmaceutical review. 2021. № 4 
Фармакологічні дослідження біологічно активних речовин Pharmacological researches of biologically active substances

ха малого. Отримані дані будуть використанні у подальших дослідження настойок та рідких екс-

Конфлікт інтересів: відсутній. трактів.

Conflicts of interests: authors have no conflicts of interests to declare.

\title{
ANTIMICROBIAL ACTIVITY OF TINCTURES AND LIQUID EXTRACTS FROM THE ROOTS OF ARCTIUM LAPPA, ARCTIUM MINUS AND ARCTIUM TOMENTOSUM
}

\author{
T. V. Oproshanska ${ }^{1}$, T. P. Osolodchenko ${ }^{2}$, O. P. Khvorost ${ }^{1}$ \\ National University of Pharmacy, Kharkiv ${ }^{1}$ \\ Mechnikov Institute of Microbiology and Immunology of the National Academy of Medical Sciences of \\ Ukraine $^{2}$ \\ arctium@ukr.net
}

The aim of the work. To determine the antimicrobial activity of tinctures and liquid extracts from the roots of Arctium lappa, Arctium minus and Arctium tomentosum.

Materials and Methods. Tinctures and liquid extracts from plant raw materials were prepared by the method of maceration, extractant $50 \%$ ethyl alcohol. The study of antimicrobial activity was performed by the method of diffusion into agar and the method of serial dilutions. The minimum inhibitory and minimum bactericidal concentration of the liquid extracts were determined.

Results and Discussion. Liquid extracts from the root of Arctium lappa, Arctium minus and Arctium tomentosum showed higher antimicrobial activity than tinctures. All strains of microorganisms were most sensitive to the liquid extract of the root of Arctium minus. Tinctures and liquid extracts showed much higher activity against the microorganisms Basillus subtilis ATCC 6633 and Staphylococcus aureus ATCC 25923. The minimum inhibitory and minimum bactericidal concentration of liquid extracts from the root of Arctium lappa and Arctium minus against Escherichia coli ATCC 25922 (for (124.90 \pm 3.94$) \mathrm{mg} / \mathrm{ml}$ and $(252.20 \pm 8.36) \mathrm{mg} / \mathrm{ml}$, respectively), liquid extract from the root of Arctium minus against Proteus vulgaris ATCC 4636 $(249.80 \pm 10.04) \mathrm{mg} / \mathrm{ml}$ and $(505.20 \pm 19.88) \mathrm{mg} / \mathrm{ml}$, respectively) and liquid extract from the root of Arctium lappa in relation to Basillus subtilis ATCC $6633(125.00 \pm 6.40) \mathrm{mg} / \mathrm{ml}$ and $(250.60 \pm 12.36) \mathrm{mg} / \mathrm{ml}$, respectively) were at the level of minimum inhibitory and minimum bactericidal concentration of chlorophyllipt in relation to these strains of microorganisms.

Conclusions. To determine the spectrum of antimicrobial activity of tinctures and liquid extracts from the root Arctium lappa, Arctium minus and Arctium tomentosum in relation to 6 museum strains of microorganisms and determine the minimum inhibitory and minimum bactericidal concentration of liquid extracts. Liquid extracts showed higher antimicrobial activity than tinctures. The obtained data will be used in further studies of tinctures and liquid extracts.

Key words: Arctium; root; tincture; liquid extract; antimicrobial activity.

Перелік бібліографічних посилань

1. Шостак Т. А., Калинюк Т. Г., Гудзь Н. І. Особливості фрармацевтичної розробки рослинних препаратів. Фітотерапія. Часопис. 2014. № 4. С. 77-82.

2. Антимікробні властивості настоянок scorzonera purpurea та hypericum perforatum / Н. Є. Стадницька та ін. Актуальні проблеми синтезу і створення нових біологічно активних сполук та орармацевтичних препаратів : мат. доп. та зб. наук. статей : інтернетконфр., 23-25 квітня 2013, Львів. Львів : Вид-во Львівської політехніки, 2013. С. 118-121.

3. Ротар Д. В., Патрабой В. В., Герасим'юк І. Г. Спектр протимікробних властивостей настоянок лікарських рослин. Актуальна інфректологія. 2016. № 2 (11). C. 24-29.

4. Garvey M.I., Rahman M.M., Gibbons S. Medicinal plant extracts with efflux inhibitory activity against Gramnegative bacteria. J. of Antimicrobial Agents. 2011. Vol. 37, No. 2. P.145-151.

5. Державний реєстр лікарських засобів України
[Електронний ресурс] / МОЗ України. Київ, 2020. URL: http: // www. drlz.kiev.ua

6. Мацюк О. Д., Вишневська Л. І., Бугай А. В. Наукове обґрунтування застосування лопуха великого в сучасній медицині та аналіз фрармацевтичного ринку препаратів на його основі. Фармацевтичний часопис. 2021. № 2. С. 44-54.

7. A review of the pharmacological effects of Arctium lappa (burdock). Y. S. Chan, L. N. Cheng, J. H. Wu et al. Inflammopharmacology. 2011. Vol. 19 (5). P. 245-254. DOI: 10.1007/s10787-010-0062-4.

8. Metabolic profile of the bioactive compounds of burdock (Arctium lappa) seeds, roots and leaves. R. Ferracane, G. Graziani, M. Gallo et al. J. Pharm. Biomed. Anal. 2010. Vol. 51 (2). P. 399-404. DOI: 10.1016/j. jpba.2009.03.018.

9. Metabolomics-based screening of biofilm-inhibitory compounds against Pseudomonas aeruginosa from Burdock Leaf. Z. Lou, Y. Tang, X. Song, H. Wang. Mole-

ISSN 2312-0967. Фармацевтичний часопис. 2021. № 4 
cules. 2015. Vol. 20 (9). P. 16266-16277. DOI: 10.3390/ molecules200916266.

10. The effect of burdock leaf fraction on adhesion, biofilm formation, quorum sensing and virulence factors of Pseudomonas aeruginosa. Z. Lou, H. Wang, Y. Tang, X. Chen. J. Appl Microbiol. 2017. Vol. 122 (3). P. 615624. DOI: $10.1111 /$ jam.13348.

11. Antibacterial, antibiofilm effect of Burdock (Arctium lappa $L$.) leaf fraction and its efficiency in meat preservation. Z. Lou, C. Li, X. Kou et al. J. Food Prot. 2016. Vol. 79 (8). P. 1404-1409. DOI: 10.4315/0362-028X. JFP-15-576.

12. Burdock (Arctium lappa L.) root attenuates preneoplastic lesion development in a diet and thioacetamide-induced model of steatohepatitis-associated hepatocarcinogenesis. G. R. Romualdo, E. D. A. Silva, T. C. Da Silva et al. Environ Toxicol. 2020. Vol. 35 (4). P. 518-527.

13. Medicinal herbs used in traditional management of breast cancer: mechanisms of action. D. A. McGrowder, F. G. Miller, C. R. Nwokocha et al. Medicines (Basel). 2020. Vol. 7 (8). P. 47. DOI 10.3390/medicines7080047.

14. Aqueous extract of Arctium lappa L. root (burdock) enhances chondrogenesis in human bone marrow-derived mesenchymal stem cells. K. C. Wu, H. K. Weng, Y. S. Hsu et al. Complement Med. Ther. 2020. Vol. 20
(1). P. 364. DOI: 10.1186/s12906-020-03158-1.

15. Effects of Arctium lappa L. (Burdock) root tea on inflammatory status and oxidative stress in patients with knee osteoarthritis. L. Maghsoumi-Norouzabad, B. Alipoor, R. Abed et al. Int. J. Rheum. Dis. 2016. Vol 19 (3). P. 255-261.

16. Moro T.M.A., Clerici M. Burdock (Arctium lappa L.) roots as a source of inulin-type fructans and other bioactive compounds: Current knowledge and future perspectives for food and non-food applications. Food. Res. Int. 2021. Vol. 141. P.109889. DOI: 10.1016/j. foodres.2020.109889.

17. Antibacterial activity of medicinal plants and their constituents in the context of skin and wound infections, considering European legislation and folk medicine a review. S. Bittner Fialová, K. Rendeková, P. Mučaji et al. Int. J. Mol. Sci. 2021. Vol. 22 (19). P. 10746. DOI: 10.3390/ijms221910746.

18. Antioxidant, antimicrobial and antiviral properties of herbal materials. S. Parham, A. Z. Kharazi, H. R. Bakhsheshi-Rad. Antioxidants (Basel). 2020. Vol. 9 (12). P. 1309. DOI: 10.3390/antiox9121309.

19. Miazga-Karska M., Michalak K., Ginalska G. Antiacne action of peptides isolated from burdock rootpreliminary studies and pilot testing. Molecules. 2020. Vol. 25(9). P. 2027. DOI: 10.3390/molecules25092027.

\section{References}

1. Shostak TA, Kalyniuk TH, Hudz NI. [Features of pharmaceutical development of herbal preparations]. Fitoterapiia. Chasopys. 2014;4: 77-82. Ukrainian.

2. Stadnytska NYe, Pavliuk IV, Dumych II, Hubytska II, Novikov VP. [Plants with antimicrobial properties]. Aktualni problemy syntezu i stvorennia novykh biolohichno aktyvnykh spoluk ta farmatsevtychnykh preparativ: mat. dop. ta zb. nauk. statei : internet-konf., 2013; 118121. Ukrainian.

3. Rotar DV, Patraboi VV, Herasymiuk IH. [The range of antimicrobial properties of medicinal plant tinctures]. Aktualna infektolohiia. 2016;2(11): 24-9. Ukrainian.

4. Garvey MI, Rahman MM, Gibbons S. Medicinal plant extracts with efflux inhibitory activity against Gram-negative bacteria. J. of Antimicrobial Agents. 2011;37(2); 145-51.

5. State Register of Medicines of Ukraine. [Internet]. 2021. [cited 2021 Sept 11]. Available from: http://www. drlz.kiev.ua Ukrainian.

6. Matsiuk OD, Vyshnevska LI, Buhai AV. [Scientific substantiation of burdock application in modern medicine and analysis of the pharmaceutical market of drugs based on it] Farmatsevtychnyi chasopys. 2021;2: 4454. Ukrainian.

7. Chan YS, Cheng LN, Wu JH. A review of the pharmacological effects of Arctium lappa (burdock). Inflammopharmacology. 2011;19(5): 245-54. DOI: 10.1007/ s10787-010-0062-4.

8. Ferracane R, Graziani G, Gallo M. Metabolic profile of the bioactive compounds of burdock (Arctium lappa) seeds, roots and leaves. J Pharm Biomed Anal.

2010;51(2): 399-404. DOI: 10.1016/j.jpba.2009.03.018.

9. Lou Z, Tang Y, Song X, Wang H. Metabolomics-based screening of biofilm-inhibitory compounds against Pseudomonas aeruginosa from burdock leaf. Molecules. 2015;20(9): 16266-77. DOI: 10.3390/molecules200916266.

10. Lou Z, Wang H, Tang Y, Chen XJ. The effect of burdock leaf fraction on adhesion, biofilm formation, quorum sensing and virulence factors of Pseudomonas aeruginosa. Appl Microbiol. 2017;122(3): 615-24. DOI: 10.1111/jam.13348.

11. Lou Z, Li C, Kou X. Antibacterial, antibiofilm effect of Burdock (Arctium lappa L.) leaf fraction and its efficiency in meat preservation. J Food Prot. 2016;79(8): 1404-9. DOI: 10.4315/0362-028X.JFP. 15-576.

12. Romualdo GR, Silva EDA, Da Silva TC. Burdock (Arctium lappa $L$.) root attenuates preneoplastic lesion development in a diet and thioacetamide-induced model of steatohepatitis-associated hepatocarcinogenesis. Environ Toxicol. 2020;35(4): 518-27.

13. McGrowder DA, Miller FG, Nwokocha CR. Medicinal herbs used in traditional management of breast cancer: Mechanisms of action. Medicines (Basel). 2020;7(8): 47. DOI 10.3390/medicines7080047.

14. Wu KC, Weng HK, Hsu YS, Huang PJ, Wang YKBMC. Aqueous extract of Arctium lappa L. root (burdock) enhances chondrogenesis in human bone marrowderived mesenchymal stem cells. Complement Med Ther. 2020;23;20(1): 364. DOI: 10.1186/s12906-02003158-1.

ISSN 2312-0967. Pharmaceutical review. 2021. № 4 
Фармакологічні дослідження біологічно активних речовин Pharmacological researches of biologically active substances

15. Maghsoumi-Norouzabad L, Alipoor B, Abed R. Effects of Arctium lappa L. (Burdock) root tea on inflammatory status and oxidative stress in patients with knee osteoarthritis. Int J Rheum Dis. 2016;19(3): 255-61.

16. Moro TMA, Clerici M. Burdock (Arctium lappa L.) roots as a source of inulin-type fructans and other bioactive compounds: Current knowledge and future perspectives for food and non-food applications. Food Res Int. 2021;141: 109889. DOI: 10.1016/j. foodres.2020.109889.

17. Bittner Fialová S, Rendeková K, Mučaji P, Nagy M, Slobodníková L. Antibacterial activity of medicinal plants

and their constituents in the context of skin and wound infections, considering European legislation and folk medicine - a review. Int J Mol Sci. 2021;4;22(19): 10746. DOI: 10.3390/ijms221910746.

18. Parham S, Kharazi AZ, Bakhsheshi-Rad HR. Antioxidant, antimicrobial and antiviral properties of herbal materials. Antioxidants (Basel). 2020;9(12): 1309. DOI: 10.3390/antiox9121309.

19. Miazga-Karska M, Michalak K, Ginalska G. Anti-acne action of peptides isolated from Burdock root-preliminary studies and pilot testing. Molecules. 2020;25(9): 2027. DOI: $10.3390 /$ molecules25092027.

\section{Відомості про авторів}

Опрошанська Т. В. - канд. фрармац. наук, доцент, кафредра хімії природних сполук і нутриціології, Національний фрармацевтичний університет, Харків, Україна. E-mail: arctium55@ukr.net, ORCID 0000-0002-3992-7183

Осолодченко Т. П. - канд. біол. наук, ст. наук. співроб., завідувачка лабораторії біохімії та біотехнології, ДУ «Інститут мікробіології та імунології імені І. І. Мечникова Національної академії медичних наук України», Харків, Україна. E-mail: imi lbb@ukr.net, ORCID 0000-0001-7258-3880

Хворост О. П. - д. фрармац. наук, професор, кафедра хімії природних сполук і нутриціології, Національний срармацевтичний університет, Харків, Україна. E-mail: khvorost09101960@gmail.com.ua, ORCID 0000-0002-95341507

\section{Information about the authors}

Oproshanska T. V. - PhD (Pharmacy), Associate Professor, Chemistry Natural Compound and Nutriciology Department, National University of Pharmacy, Kharkiv, Ukraine. E-mail: arctium55@ukr.net, ORCID 0000-0002-3992-7183

Osolodchenko T. P. - PhD (Biology), Associate Professor, Head of the Biochemistry and Biotechnology Laboratory, Mechnykov Institute of Microbiology and Immunology of the National Academy of Medical Sciences of Ukraine, Kharkiv, Ukraine. E-mail: arctium55@ukr.net, ORCID 0000-0002-3992-7183.

Khvorost O. P. - DSc (Pharmacy), Professor, Chemistry Natural Compound and Nutriciology Department, National University of Pharmacy, Kharkiv, Ukraine. E-mail: khvorost09101960@gmail.com, ORCID 0000-0002-9534-1507. 